\title{
Pengobatan Cefixime pada Demam Tifoid Anak
}

\author{
Sri Rezeki S Hadinegoro, Alan R Tumbelaka, Hindra Irawan Satari
}

Telah dilakukan penelitian uji klinis non-komparatif pengobatan cefixime terhadap demam tifoid anak di Bagian Ilmu Kesehatan Anak FKUI-RSCM Jakarta, sejak Mei 1999 - Januari 2000. Subyek berumur antara 3-15 tahun dengan diagnosis klinis demam tifoid tanpa komplikasi. Di antara 25 orang pasien yang ikut dalam penelitian, terdapat 11 laki-laki dan 14 perempuan, $16(64 \%)$ pasien termasuk kelompok 5-9 tahun dan 8 $(32 \%)$ berumur $>10$ tahun. Delapan belas anak menderita demam di rumah selama 7 hari atau lebih. Selain demam, mual, muntah, perasaan tidak enak di perut, delirium dan hepatomegali merupakan gejala yang terbanyak ditemukan. Lebih dari separuh jumlah kasus menderita demam antara $37,5-38,5^{\circ} \mathrm{C}$ dan 7 anak lainnya mengalami demam lebih dari $39^{\circ} \mathrm{C}$. Peningkatan LED dan SGOT/SGPT terdapat pada hampir semua kasus. Semua pasien mendapat pengobatan cefixime $10-15 \mathrm{mg} / \mathrm{kgbb} / \mathrm{hari}$, dibagi 2 dosis selama 10 hari. Penurunan suhu (time of fever defervescence) terjadi setelah 6,0 hari (SB 3,1) pengobatan. Cure rate, yang menggambarkan efikasi cefixime terdapat pada $21(84 \%)$ dan gagal $4(16 \%)$ kasus. Penilaian hasil pengobatan hari kelima pada 21 kasus menunjukkan 11 pasien sembuh sempurna, 10 pasien lainnya keadaan klinis baik namun masih demam dan suhu turun pada hari berikutnya. Kegagalan bakteriologis dijumpai pada 1 kasus, termasuk dalam kelompok gagal secara klinis. Secara bakteriologis, 3 pasien resisten terhadap salah satu dari ketiga antibiotik konvensional. Satu orang pasien resisten chloramphenicol dan 2 orang resisten ampisilin. Dua puluh satu $(84 \%)$ di antara 25 pasien tetap sensitif terhadap ketiga antibiotik konvensional. Dalam penelitian ini tidak terdapat satu kasus pun dengan MDRST. Secara umum cefixime mempunyai efikasi yang baik dan dapat ditoleransi oleh semua pasien dengan efek samping ringan. Untuk mendapatkan hasil yang optimal diperlukan evaluasi lebih lanjut mengenai dosis dan lama pengobatan.

Kata kunci: cefixime, multiple drug resistance, Salmonella typhi.

Dipresentasikan pada Simposium The Update on New Drugs and Methods in Medicine, oleh Fakultas Kedokteran Universitas Padjadjaran, PERALMUNI, IDAI, PERBANI, PDGMI. Hotel Hyatt Regency Bandung, 6-8 Oktober 2000.

Subbagian Infeksi dan Penyakit Tropis, Bagian Ilmu Kesehatan Anak FKUI-RSCM Jakarta (Prof. DR. Dr. Sri Rezeki S Hadinegoro, Sp.A(K), Dr. Alan R Tumbelaka, Sp.A(K) dan Dr. Hindra Irawan Satari, Sp.A(K)).

Alamat korespondensi:

Prof. DR. Dr. Sri Rezeki S Hadinegoro, Sp.A(K).

Kepala Subbagian Infeksi dan Penyakit Tropis, Bagian Ilmu Kesehatan Anak FKUI-RSCM, Jl. Salemba no. 6 Jakarta 10430.

Tel. 391 4126. Fax. 3907743.
47 Infeksi salmonela atau salmonelosis merupakan penyakit endemis yang banyak dijumpai pada anak, khususnya di negara beriklim tropis. Di antara salmonelosis, demam tifoid merupakan satu-satunya bentuk infeksi Salmonela typhi sistemik sebagai akibat dari bakteriemia yang terjadi. Secara klinis manifestasi demam tifoid pada anak tidak seberat dewasa, namun demikian pada demam tifoid yang mengalami komplikasi mortalitas meningkat sekitar 1-5\%. ${ }^{1}$ Rendahnya resistensi tubuh pada anak dan keadaan bakteri khususnya jumlah bakteri yang masuk, virulensi, maupun resistensi bakteri terhadap antibiotik yang diberikan menyebabkan demam tifoid 
kadangkala menjadi berat. ${ }^{2}$

Chloramphenicol sampai saat ini masih merupakan obat pilihan lini pertama (first drug of choice) untuk pengobatan demam tifoid pada anak. Di samping chloramphenicol, antibiotik lain yang dipergunakan untuk mengobati demam tifoid pada anak adalah kotrimoksazol dan ceftriaxone. ${ }^{1,2}$ Sementara itu, dalam lima tahun terakhir telah dilaporkan kasus demam tifoid berat pada anak bahkan fatal yang disebabkan oleh adanya resistensi obat ganda terhadap Salmonella typhi (multiple drugs resistance Salmonella typhi $=$ MDRST). ${ }^{3-}$ ${ }^{6}$ Walaupun sampai saat ini belum ada laporan resistensi Salmonella typhi pada demam tifoid anak di Indonesia, termasuk RS. Dr.Cipto Mangunkusumo (RSCM) Jakarta, strategi pengobatan MDRST perlu dibuat untuk mengantisipasi bila suatu saat kita menjumpainya. ${ }^{3}$

Cefixime merupakan antibiotik golongan sefalosporin generasi ketiga oral, mempunyai aktifitas antimikroba terhadap kuman Gram positif maupun negatif termasuk Enterobacteriacea. Pada pemberian secara oral, hampir $50 \%$ segera mencapai konsentrasi bakterisidal dan menembus jaringan dengan baik. ${ }^{7}$ Berdasarkan sifat-sifat cefixime tersebut, maka agaknya obat ini dapat dipergunakan untuk mengobati demam tifoid.

Tujuan dari penelitian ini ialah untuk mempelajari cefixime sebagai antibiotik alternatif untuk pengobatan demam tifoid anak, guna mengatasi apabila pengobatan lini pertama tidak dapat diberikan.

\section{Bahan dan Cara}

Penelitian uji klinis non-komparatif pada pengobatan cefixime untuk demam tifoid pada anak telah dilakukan di Bagian Ilmu Kesehatan Anak FKUI/ RSCM Jakarta, selama 9 bulan sejak bulan Mei 1999 sampai dengan Januari 2000. Subyek yang ikut dalam penelitian berumur antara 3-15 tahun dengan diagnosis klinis demam tifoid tanpa komplikasi. Diagnosis klinis demam tifoid ditegakkan berdasarkan pada demam 6 hari atau lebih (suhu $38^{\circ} \mathrm{C}$ atau lebih), mual, muntah, lidah tifoid, perasaan tidak enak di perut (abdominal discomfort), diare atau obstipasi, pembesaran hati dan atau limpa, delirium, dapat juga disertai kesadaran menurun. Diagnosis dikonfirmasi dengan biakan darah terhadap Salmonella typhi dengan metoda Bac-tect, dilakukan pula uji serologi Widal dan uji imunobloting Typhi-dot. Kriteria inklusi ialah (1) dapat minum obat secara oral, (2) tidak ada riwayat hipersensitivitas terhadap antibiotik, (3) dan tidak menderita penyakit infeksi lain misalnya tuberkulosis, infeksi saluran kemih, demam berdarah dengue, atau penyakit hati.

Setelah diberikan surat persetujuan turut dalam penelitian (informed consent), dilakukan pemeriksaan darah perifer lengkap, laju endap darah, urin dan tinja lengkap, biakan darah dan uji serologis, SGOT/SGPT serta ureum dan kreatinin dilakukan saat awal pengobatan dan akhir pengobatan. Semua kasus mendapat pengobatan cefixime (Cefspan) oral, 10-15 $\mathrm{mg} / \mathrm{kg}$ berat badan/hari, dalam dua kali pemberian selama 10 hari. Pemantauan dilakukan setiap hari selama dirawat sampai pengobatan selesai. Apabila biakan atau uji serologis negatif, pasien dikeluarkan dari penelitian. Kegagalan pengobatan apabila demam menetap dan atau secara klinis tampak toksis setelah pengobatan 7 hari. Pada kasus yang dinyatakan gagal pengobatan diganti dengan chloramphenicol atau ceftriaxone, tergantung dari keadaan klinis pasien dan hasil uji resistensi.

\section{Hasil Penelitian dan Pembahasan}

Dari 31 kasus demam tifoid, 6 orang di antaranya dikeluarkan dari penelitian oleh karena baik biakan maupun uji serologis terhadap Salmonella typhi negatif. Jadi hanya 25 pasien yang akan dilaporkan, terdiri dari 11 laki-laki dan 14 perempuan, 16 (64\%) pasien kelompok umur 5-9 tahun dan $8(32 \%)$ pasien $>10$ tahun (Tabel 1).

Delapan belas anak telah mengalami demam di rumah selama 7 hari atau lebih. Selain demam, mual, muntah, perasaan tidak enak di perut, delirium dan hepatomegali merupakan gejala yang terbanyak ditemukan. Lebih dari separuh jumlah kasus menderita demam antara $37,5-38,5^{\circ} \mathrm{C}$ dan 7 anak lainnya mengalami demam lebih dari $39^{\circ} \mathrm{C}$. Peningkatan LED dan SGOT/SGPT terdapat pada hampir semua kasus. (Tabel 2)

\section{Lama Demam Reda (time of fever defer- vescence)}

Cefixime sebagai antibiotik sefalosporin generasi ketiga mempunyai beberapa sifat khususnya pada demam tifoid anak, yaitu (1) Aktifitas bakterisidal cefixime 
Tabel 1. Lama Demam dan Pola Suhu Saat Masuk Rumah Sakit

\begin{tabular}{llcccc}
\hline \multirow{2}{*}{$\begin{array}{l}\text { Kelompok Umur } \\
\text { (tahun) }\end{array}$} & \multicolumn{4}{l}{ Lama Demam (hari) } & \multicolumn{3}{c}{ Suhu Saat Masuk (o C ) } \\
\cline { 2 - 6 } & $<7$ & $\geq 7$ & $38,0-38,5$ & $38,5-39,0$ & $>39.0$ \\
\hline$<5$ & 0 & 1 & 1 & 0 & 0 \\
$5-9$ & 4 & 11 & 10 & 2 & 4 \\
$\geq 10$ & 3 & 6 & 3 & 2 & 3 \\
Jumlah & 7 & 18 & 14 & 4 & 7 \\
\hline
\end{tabular}

Tabel 2. Manifestasi klinis

\begin{tabular}{ll}
\hline Gejala klinis & $\mathrm{n}$ \\
\hline Demam & 25 \\
Menggigil & 15 \\
Nyeri perut & 18 \\
Mual & 20 \\
Muntah & 21 \\
Diare & 12 \\
Obstipasi & 13 \\
Mengigau & 20 \\
Kesadaran menurun & 10 \\
Lidah tifoid & 15 \\
Nyeri epigastrium & 17 \\
Hepatomegali & 19 \\
Splenomegali & 6 \\
\hline
\end{tabular}

* tiap pasien dapat mempunyai lebih dari satu gejala

tergantung dari waktu tercapainya konsentrasi dalam serum di atas minimal inhibitory concentration (MIC) dari organisme. Sebagai akibatnya perlu ditentukan dosis cefixime untuk mempertahankan kadar di atas ambang optimal. (2) Cefixime dapat menembus jaringan dengan baik, dapat melakukan penetrasi ke tempat inflamasi dan makrofag yang terinfeksi, sehingga di tempat inflamasi akan tercapai konsentrasi di atas MIC. Pada kasus pediatri, kadar cefixime tertinggi dalam plasma $4,04 \mathrm{ug} / \mathrm{ml}$ yang dicapai dalam waktu 3,2 jam, sedangkan half-life waktu eliminasi ratarata adalah 3,91 jam. (3) Cefixime sangat efektif terhadap bakteri Gram negatif termasuk S.typhi dengan kadar MIC90 <0,25 (range 0,06-0,5 ug/ml). (4) Secara in-vitro, cefixime efektif untuk S.typhi yang telah resisten terhadap amoksisilin. ${ }^{7}$

Berdasarkan sifat-sifat cefixime tersebut di atas, maka penentuan dosis, berapa kali pemberian dalam sehari, dan lama pengobatan sangat penting untuk mendapatkan hasil yang optimal. Para meter penilaian keberhasilan pengobatan demam tifoid dilihat dari lama (hari) terjadinya penurunan suhu (time of fever deferfescence), keberhasilan klinis maupun bakteriologis, dan ada tidaknya relaps. Pada penelitian ini dengan pengobatan cefixime $10-15 \mathrm{mg} / \mathrm{kgBB} /$ hari diberikan dalam dua dosis selama 10 hari, maka penurunan suhu terjadi setelah 5,7 hari (SB 2,1) pengobatan. Apabila dibandingkan dengan penelitian terdahulu dengan pengobatan chloramphenicol suhu lebih cepat reda (rerata 4,3 hari), ${ }^{1}$ dan hampir sama dengan pengobatan sefalosporin parenteral ceftriaxone intravena yaitu 5,4 hari, (SB 1,5). ${ }^{8}$ (Tabel 3)

Tabel 3. Lama Demam Reda

\begin{tabular}{ccc}
\hline $\begin{array}{c}\text { Lama Demam Turun } \\
\text { (hari) }\end{array}$ & $\mathrm{n}$ & $\mathrm{x}$ \\
\hline 3 & 4 & 12 \\
4 & 4 & 16 \\
5 & 2 & 10 \\
6 & 4 & 24 \\
7 & 4 & 28 \\
8 & 3 & 24 \\
9 & 4 & 36 \\
\hline Jumlah & 25 & 133 \\
\hline Rerata & 6,0 & $($ SD 3,1) \\
\hline
\end{tabular}

Girgis NI ${ }^{4}$ melakukan uji klinis dalam dua tahap, pertama dengan pemberian cefixime $10 \mathrm{mg} / \mathrm{kgBB} / \mathrm{hari}$ dibagi dalam dua dosis selama 12 hari, didapatkan hasil cukup efektif dan aman. Penelitian kedua merupakan uji kilinis komparatif yaitu 50 pasien diobati dengan cefixime $25 \mathrm{mg} / \mathrm{kgBB} /$ hari single dose selama 8 hari, 43 pasien mendapat pengobatan ceftriaxone $65 \mathrm{mg} / \mathrm{kgBB} /$ hari intramuskular dosis tunggal selama 5 hari, dan 31 pasien mendapat aztreonam $50 \mathrm{mg} / \mathrm{kgBB} / \mathrm{hari}$ 
dibagi dalam 3 dosis selama 7 hari. Semua pasien dinyatakan sembuh, tetapi 3 orang yang mendapat cefixime terjadi relaps setelah 2 minggu pengobatan dihentikan dan 2 orang relaps pada pengobatan masingmasing ceftriaxone dan aztreonam. Sedangkan apabila dibandingkan antara uji klinis dosis pertama dan kedua, (1) penurunan suhu pada dosis $10 \mathrm{mg} \mathrm{mg} /$ $\mathrm{kgBB} / \mathrm{hari}$ dua dosis selama 12 hari adalah 6 hari sedangkan pada dosis $25 \mathrm{mg} / \mathrm{kgBB} /$ hari single dose selama 8 hari, sedikit lebih lama. (2) terdapat kegagalan pada 3 kasus baik secara klinis maupun bakteriologis pada pemberian cefixime dengan dosis $25 \mathrm{mg} / \mathrm{kgBB} /$ hari single dose selama 8 hari. (3) relaps lebih banyak (3 orang) pada kelompok pada dosis $10 \mathrm{mg} \mathrm{mg} / \mathrm{kgBB} /$ hari dua dosis selama 12 hari daripada kelompok dosis $25 \mathrm{mg} / \mathrm{kgBB} /$ hari single dose selama 8 hari (1 orang). $\mathrm{Hal}$ ini memberikan kesan bahwa dosis $10 \mathrm{mg} \mathrm{mg/}$ $\mathrm{kgBB} /$ hari dibagi dalam dua dosis selama 12 hari lebih efektif, namun relaps rate lebih tinggi maka masih diperlukan penelitian lebih lanjut.

\section{Cure Rate}

Di antara 25 kasus, cure rate secara klinis terdapat pada $21(84 \%)$ dan gagal 4 (16\%). Kegagalan bakteriologis dijumpai pada 1 kasus, termasuk dalam kelompok gagal secara klinis. Kasus pertama menderita demam yang menetap setelah 5 hari pengobatan dan pada saat itu kesadaran pasien menurun. Kasus ke-2 menderita komplikasi pneumonia dan demam tinggi pada hari ketujuh pengobatan. Sedangkan kasus ke-3 resisten terhadap cefixime dan demam menetap setelah 5 hari pengobatan, dan kasus ke-4 mengalami urtikaria hebat seluruh badan pada hari ketiga pengobatan sehingga pengobatan cefixime dihentikan. Pada dua kasus pertama, pengobatan diganti dengan sefalosporin parenteral (ceftriaxone) sedangkan pada dua kasus berikutnya pengobatan diganti dengan chloramphenicol dengan hasil baik.

Berdasarkan data tersebut di atas, maka efikasi pengobatan cefixime pada demam tifoid anak di Bagian Ilmu Kesehatan Anak RS. Dr. Cipto Mangunkusumo Jakarta adalah $84.0 \%$ (21 di antara 25 pasien). Di antara 25 kasus, 11 sembuh sempurna dalam 5 hari pengobatan, 10 pasien lainnya masih demam setelah 5 hari pengobatan namun keadaan klinis pasien baik (kesadaran membaik, gejala abdominalis menghilang, nafsu makan membaik, dan tidak terjadi komplikasi); sedangkan 4 orang anak gagal dalam pengobatan. (tabel 4)

Table 4. Hasil Pengobatan Secara Klinis

\begin{tabular}{lll}
\hline Hasil Pengobatan & $\mathrm{n}$ & $\%$ \\
\hline Sembuh & 21 & 84,0 \\
Gagal & 4 & 16,0 \\
\hline Jumlah & 25 & 100 \\
\hline
\end{tabular}

Tabel 5 memperlihatkan hasil penelitian uji klinis cefixime dengan berbagai dosis, cara dan lama pemberian pada demam tifoid anak dari beberapa negara.

\section{Resistensi Antibiotik}

Telah dilaporkan di Pakistan, Mesir, Mexico, Vietnam dan Thailand sejak tahun 1988, MDRST terdapat pada 50-75\% kasus demam tifoid anak. ${ }^{3-6}$ Resistensi obat ganda terhadap Salmonella typhi adalah adanya galur (strain) Salmonella typhi yang telah resisten terhadap dua atau lebih antibiotik yang dipergunakan untuk pengobatan demam tifoid secara konvensional, yaitu ampisilin, chloramphenicol, dan kotrimoksazol. Pemberian antibiotik yang berlebihan (over-use), pemakaian antibiotik yang salah (mis-use), atau pemakaian antibiotik yang tidak tepat (inappropriate) merupakan penyebab terjadinya MDRST di samping kemungkinan adanya faktor plasmid mediated. Dalam menghadapi kasus resistensi terhadap Salmonella typhi dengan mortalitas yang cenderung lebih tinggi daripada non-MDRST, maka akan diperlukan antibiotik yang lebih poten seperti golongan sefalosporin injeksi atau aztreonam. Pada kasus dewasa kasus MDRST telah berhasil diobati kuinolon, namun sampai sekarang FDA tidak merekomendasikan pemakaian kuinolon pada anak mengingat efek samping artropati pada tulang rawan. ${ }^{9}$

Bakteriemia persisten pada hari keempat pengobatan terjadi pada 1 orang pasien yang termasuk pada 4 orang pasien yang gagal dalam pengobatan, jadi pasien tersebut mengalami kegagalan secara klinis dan bakteriologis. Pada pemeriksaan bakteriologis, 3 orang pasien resisten terhadap salah satu dari ketiga antibiotik konvensional untuk pengobatan demam tifoid yaitu ampisillin, chloramphenicol, dan kotrimoksazol. Satu 
Table 5. Ringkasan Pengobatan Cefixime pada Demam Tifoid Anak

\begin{tabular}{|c|c|c|c|c|c|c|}
\hline Peneliti & Uji Klinis & Dosis & $\begin{array}{l}\text { Saat Demam } \\
\text { Reda }\end{array}$ & $\begin{array}{l}\text { Hasil } \\
\%\end{array}$ & $\begin{array}{l}\text { Gagal } \\
\%\end{array}$ & $\begin{array}{l}\text { Efek } \\
\text { Samping }\end{array}$ \\
\hline Bhutta ZA, dkk & Komparatif & $10 \mathrm{mg} / \mathrm{kgbb}$ & Ceftri 6.9 (6.4) & 88 & 12 & diare \\
\hline Pakistan, 1994 & $\begin{array}{l}\text { Ceftr }(n=40) \\
\text { Cefix }(n=40)\end{array}$ & $\begin{array}{l}2 \text { dosis } \\
14 \text { hari }\end{array}$ & Cefix $6.4(2.0)$ & & & $\begin{array}{l}\text { peningkatan } \\
\text { SGPT }\end{array}$ \\
\hline $\begin{array}{l}\text { Girgis NI, dkk } \\
\text { Egypt, } 1995\end{array}$ & $\begin{array}{l}\text { Non- } \\
\text { komparatif } \\
\text { Cefix }(n=60)\end{array}$ & $\begin{array}{l}20-30 \mathrm{mg} / \mathrm{kgbb} \\
2 \text { dosis } \\
12 \text { hari }\end{array}$ & Cefix $5.7(2.1)$ & 95 & 5 & $\begin{array}{l}8 \% \\
\text { diare ringan } \\
\text { muntah }\end{array}$ \\
\hline $\begin{array}{l}\text { Memon IA, dkk } \\
\text { Pakistan, } 1997\end{array}$ & $\begin{array}{l}\text { Komparatif } \\
\text { Cefix }(n=41) \\
\text { Chloro }(n=44)\end{array}$ & $\begin{array}{l}10-12 \mathrm{mg} / \mathrm{kgbb} \\
2 \text { dosis, } \\
2 \text { minggu }\end{array}$ & $\begin{array}{ll}\text { Cefix } & 5.6 \\
\text { Chloro } & 4.4\end{array}$ & $\begin{array}{l}95 \\
30\end{array}$ & $\begin{array}{l}5 \\
70\end{array}$ & $2 \%$ \\
\hline $\begin{array}{l}\text { Hadinegoro SR, dkk } \\
\text { Indonesia, } 2000\end{array}$ & $\begin{array}{l}\text { Non- } \\
\text { komparatif } \\
\text { Cefix }(n=25)\end{array}$ & $\begin{array}{l}10-15 \mathrm{mg} / \mathrm{kgbb} \\
2 \text { dosis } \\
10 \text { hari }\end{array}$ & Cefix $6.0(3.1)$ & 84 & 16 & $\begin{array}{l}\text { diare ringan } \\
\text { muntah } \\
\text { urtikaria }\end{array}$ \\
\hline
\end{tabular}

Note: $\quad$ cefix=cefixime, ceftr=ceftriaxone, chloro=chloramphenicol

orang pasien resisten terhadap chloramphenicol dan dua orang lainnya resisten terhadap ampisilin. Jadi, 21 (84\%) di antara 25 pasien tetap sensitif terhadap ketiga antibiotik konvensional. Tidak terdapat satu kasus pun MDRST dalam penelitian ini.

Billoo $\mathrm{AG}^{10}$ telah melakukan uji klinis komparatif pada 41 anak yang mendapat cefixime $10-12 \mathrm{mg} / \mathrm{kgBB} /$ hari dibagi dua dosis selama dua minggu dibandingkan dengan 44 anak dengan pengobatan chloramphenicol $100 \mathrm{mg} / \mathrm{kgBB} / \mathrm{hari}$ dalam empat kali pemberian selama dua minggu, didapatkan $77 \%$ kasus resisten terhadap ketiga antibiotik konvensional dan hanya 15\% sensitif. Namun hal ini disebabkan oleh karena kasus yang dilaporkan adalah kasus rujukan dari daerah yang telah mendapat berbagai antibiotik sebelumnya. Dilaporkan pula bahwa community resistent MDSRST rate pada tahun 1990-1994 sebesar 56\%. Dalam penelitiannya cure rate terdapat pada 41 (95\%) dan hanya $13(30 \%)$ kasus sembuh dengan pengobatan chloramphenicol.

Untuk mengetahui kasus MDRST, Bhutta Z. ${ }^{11}$ mempergunakan sistem skoring dalam menilai keadaan klinis dan laboratorium. Pada kasus MDRST umumnya secara klinis anak sakit lebih lama, demam tinggi, anak tampak toksis, dijumpai hepatomegali yang nyata, disertai peningkatan inflammatory marker seperti CRP (C-reactive protein). Apabila dijumpai skoring $>4$ maka diduga adanya kasus MDRST sedangkan kasus yang masih sensitif mempunyai skor $<3$. Pada tatalaksana kasus MDRST atau kasus demam tifoid yang tidak tampak perbaikan setelah pengobatan 3 hari, maka cefixime merupakan pilihan pertama dan apabila gagal maka dianjurkan pemberian ciprofloxacin atau aztreonam. Namun, di Indonesia pemberian quinolon (ciprofloxacin) pada anak tidak dianjurkan.

\section{Toleransi dan Efek Samping}

Secara umum cefixime dapat ditoleransi baik oleh semua pasien. Efek samping ringan berupa mual/ muntah terdapat pada 2 pasien namun tidak sampai perlu diganti dengan antibiotik lain. Urtikaria terjadi pada satu pasien setelah 3 hari pengobatan cefixime dan menghilang setelah pengobatan cefixime dihentikan. Tidak dijumpai perubahan baik pada kadar enzim hati maupun fungsi ginjal pada semua pasien selama pengobatan cefixime.

\section{Kesimpulan}

Sebagai kesimpulan, cefixime mempunyai efikasi dan 
Tabel 6. Efek Samping

\begin{tabular}{|c|c|c|}
\hline Efek Samping & $\mathrm{n}$ & Keterangan \\
\hline Urtikaria & 1 & $\begin{array}{l}\text { Hari ketiga pengobatan timbul urtikaria seluruh tubuh, } \\
\text { ganti chloramphenicol }\end{array}$ \\
\hline Peningkatan SGOT/SGPT & 0 & Tidak ada \\
\hline Peningkatan ureum/ kreatinin & 0 & Tidak ada \\
\hline Drop out & 3 & $\begin{array}{l}\text { - Demam tidak turun } 5 \text { hari, klinis memburuk, ganti ceftriaxone } \\
\text { - Timbul komplikasi (pneumonia), pengobatan cefixime } 10 \text { hari } \\
\text { demam tidak turun, ganti cefotaxime. } \\
\text { - Demam tidak turun } 5 \text { hari (biakan resisten terhadap cefixime), } \\
\text { ganti ceftriaxone. }\end{array}$ \\
\hline
\end{tabular}

toleransi yang baik untuk pengobatan demam tifoid anak. Untuk mendapatkan hasil yang optimal, dosis dan lama pengobatan perlu dievaluasi lebih lanjut. Meskipun di Bagian IKA FKUI-RSCM Jakarta sampai saat ini belum dijumpai MDRST, cefixime dapat dipergunakan sebagai obat alternatif pengobatan demam tifoid khususnya apabila chloramphenicol tidak dapat diberikan (misalnya jumlah leukosit $<2.000 / u l$, adanya hipersensitif terhadap chloramphenicol, atau Salmonella typhi resisten terhadap chloramphenicol).

\section{Daftar Pustaka}

1. Ringo-Ringo PH. Pola resistensi antibiotik pada penderita demam tifoid anak di Bagian Ilmu Kesehatan Anak FKUI.RSCM Jakarta Tahun 1990-1994. Tesis Program Studi ilmu Kesehatan Anak Fakultas Kedokteran Universitas Indonesia, Jakarta 1996.

2. Hadinegoro SR. Masalah multiple drug resistance pada demam tifoid anak. Dipresentasikan pada simposium New treatment of typhoid fever in children. Jakarta, 26 Agustus 1998.

3. Bhutta ZA, Khan IA, Molla AM. Therapy of multidrugresistant typhoid fever with oral cefixime vs. intravenous ceftriaxone. Pediatr Infect Dis J 1994; 13:990-4.

4. Girgis NI, Sultan Y, Hammad O, Farid ZH. Comparison of the efficacy, safety, and cost of cefixime, ceftriaxone, and aztreonam in the treatment of multidrug-resistant Salmonella typhi septicemia in children. Pediatr Infect Dis J 1995; 14:603-5.

5. Mirza SH. The prevalence and clinical features of multidrug resistant Salmonella typhi infections in Baluchistan, Pakistan. Ann of Trop Med and Parasitol 1995; 89:5139.

6. Memon IA, Billoo AG, Memon HI. Cefixime: An oral option for the treatment of multidrug-resistant enteric fever in children. South Med J 1998; 90:1204-7.

7. Matsumoto K. Pharmacokinetics/pharmacodynamics and in-vitro antimicrobial activity of cefixime for Salmonella typhi. Third Asia Pacific Symposium on Thyphoid Fever and Other Salmonellosis. Bali, 11 Desember 1997.

8. Hadinegoro SR. Pengobatan ceftriaxone dosis satu kali sehari pada demam tifoid anak. Dipresentasikan pada KONIKA IX, di Semarang 13-17 Juni 1993.

9. Hadinegoro SR. Kuinolon pada anak suatu dilema. Dalam: Alan RT, Hadinegoro SR, Oswari H. penyunting. Naskah lengkap pendidikan kedokteran berkelanjutan Bagian Ilmu Kesehatan Anak XL. Balai Penerbit Universitas Indonesia, Jakarta. 1997:133-40.

10. Billoo AG. Cefixime: An oral option for the treatment of MDR enteric fever in children. Third Asia Pacific Symposium on Thyphoid Fever and Other Salmonellosis. Bali, 11 Desember 1997.

11. Bhutta ZA. MDR Typhoid: a potential algorithmic approach to diagnosis and management. Third AsiaPacific Symposium on Typhoid Fever and Other Salmonellosis. Bali, 11 Desember 1997. 